Review

\title{
The Legal Structure of Taiwan's Wetland Conservation Act
}

\section{Yi-Yuan Su ${ }^{1,2}$}

1 Graduate School of Law, Hokkaido University, Sapporo 060-0809, Japan;

E-Mail: suyiyuan@juris.hokudai.ac.jp; Tel.: +81-11-706-3074

2 Department of Law, National Chung Hsing University, Taichung 402, Taiwan;

E-Mail: suyiyuan@nchu.edu.tw

External Editor: Marc A. Rosen

Received: 8 September 2014; in revised form: 5 December 2014 / Accepted: 8 December 2014 / Published: 16 December 2014

\begin{abstract}
In July of 2013, Taiwan passed its Wetland Conservation Act and will begin the implementation of the Act on 2 February 2015. With this Act, Taiwan has become the second Asian country to have specific legislation on wetland conservation and protection. This new law enables the society to achieve sustainable utilization on wetland ecological services. The core concepts of the Wetland Conversation Act include biological diversity conservation and wise use of wetland resources. Special political circumstances prevent Taiwan from registering its wetlands as a conservation priority under the Ramsar Convention. This new law allows the government to evaluate and assign a specific area as a "Wetland of Importance." Under this status, any development activities within the designated area shall be prohibited unless the developer prepares a usage plan for review. The usage plan and the original usage of the natural resources within the wetland area shall also follow the "wise use" principle to protect the wetland and biological service system. However, this new law does not provide clear separation between the two different "wise use" standards. If the development is deemed necessary, new law provides compensation mitigation measures to extend the surface of the wetland and provides additional habitats for various species. Wetland conservation and management rely heavily on systematic research and fundamental data regarding Taiwan's wetlands. Determining how to adopt these scientific methodologies and transfer them into enforceable mechanisms is a sizeable challenge for both biologists and lawyers as the Wetland Conservation Act creates many legal norms without clarifying definitions. This article will review the current wetland regulations from the legal perspective and provide suggestions for enforcement in the future.
\end{abstract}


Keywords: wetlands; Ramsar Convention on Wetlands; wise use; wetland of importance; wetland fund; avoidance; mitigation; compensation; wetland label

\section{Introduction}

The Legislative Yuan of the Republic of China (known as Congress of Taiwan) passed its Wetland Conservation Act (hereinafter referred to as the Wetland Act) contains 42 articles [1] and was decreed by Presidential Order No. Hua-Zong-Yi-Yi 10200127201 on 3 July 2013 [2]. The implementation date was set for 2 July 2014, but was changed to 2 February 2015 by the Executive Order Yuan-Tai-Chian-Tze No. 1030030131 on 12 June 2014 [3]. The Wetland Act is a unique piece of legislation in Northeast Asia. Only South Korea and Taiwan have specific laws to protect their domestic wetlands. The Wetland Act is a voluntary implementation measure put forth by the non-Ramsar Convention Party (The Convention on Wetlands of International Importance Especially Waterfowl Habitat, Ramsar, 1971; hereinafter referred to as the Ramsar Convention) [4].

Taiwan's establishment of the Wetland Act arose from protesting of a development project of the Kuo-Kuang petrochemical plant project in 2005. The site of the development project was located on the delta of the Zuo-Shui River in central Taiwan. The delta is an intertidal zone with abundant marine species and is the habitat of the endangered migratory bird, the Eastern Curlew (Numenius madagascariensis). [5] Both citizens and environmental groups challenged the necessity of building petrochemical factories in this important wetland. They expressed their deep concern that the development of the petrochemical industry in this area would negatively impact the local environment and public health in the future. During six years of discussion and debating, some environmental groups and citizens implored the government to create a legislative proposal to protect wetlands on the island from further rapid, economic developments. They insisted the definition of wetland cover various types of wetlands, but not be limited to coastal area wetlands. Accordingly, the Ministry of the Interior, the party responsible for the legislation, assigned the Coastal Restoration Urban and Rural Development Branch of the Construction and Planning Agency to study and draft a proposal for wetland protection in 2009. At the same time, some environmentalists, scholars, and NGO members merged their opinions to prepare their own proposals for further negotiation with government. In the final stages, there were five different proposals raised to the Legislative Yuan by various representatives. In April of 2012, during the proposal negotiation and editing, the President cancelled the petrochemical plant project because of adverse environmental impact concerns from the project and the rise of the global crude oil price. However, the wetland protection legislation process continued and finally passed on 14 June 2013.

The wetland legislation in Taiwan is a great achievement of sustainable utilization on Taiwan's wetland ecological services; especially because it was contributed from a button up proposal from citizens. This Wetland Act not only provide an effective measure for the country to protect its wetland resources but also prove the influences to an non-Ramsar Contracting Patty from the international treaties. The international treaties do provide proper references materials to the individual county. They enhance the global wetland protection through promoting domestic legislation and enforcements. 


\section{General Legal Principles}

Article 18 of the Basic Environment Act is the source of the legal authority supporting the Wetland Conservation Act [6]. The Basic Environmental Act provided "sustainable development" and "polluter pay" principles to guide all environment regulations in Taiwan. Article 18 states all levels of government entities shall take aggressive measures to protect wetland environments. The central government responded to Article 18's requirement to establish wetland protection regulations and followed its general principles to design regulations for wetland conservation. However, there are eight chapters in the Wetland Act, and none of them adopt the "sustainable development" and "polluter pay" principle [5] described in the Basic Environment Act. On the other hand, Article 1 of the Wetland Act states the core concepts of this Wetland Act are "biological diversity conservation" and "wise use" of wetland ecological services [1]. This means the measurements and regulations are based on "wise use" as defined in Article 4 [1].

Because the Basic Environment Act is the basic and fundamental regulation for all environmental regulations in Taiwan, it is not clear whether the "wise use" principle used in the Wetland Act fits the sustainable development principle described in the Basic Environment Act. Paragraph 2, Article 2 of the Basic Environment Act defines sustainable development as "satisfying contemporary needs without sacrificing the ability of future generations to satisfy their needs" [6]. This definition follows the definition provided by the World Commission on Environment and Development in 1987. However, the purpose and definition of the "wise use" principle is obviously different from the sustainable development definition as the sustainable development, or "wise use" definition, is more focused on the sustainable utilization of wetland resources only. It is not clear whether the usage of the wetland ecological services will only concern the stable conditions of wetlands and ignore the sustainable development of economic, society and institutions, particularly the biological diversity conversation goal of this new bill.

Article 4 of the Wetland Act states the wise use principal is predominantly focused on the sustainable utilization on biological resources, water resources, and land resources within its ecological capacities and achieves stable conditions of wetland resources [2]. As part of environment regulations, this new law does not follow and connect with the regulations provided by the Basic Environment Act.

The Ministry of Interior explained the principle of "wise use" is a legal standard adopted from the decision made by the third meeting of Conference of the Contracting Parties of Ramsar Convention in 1987 [7]. However, Taiwan is not a member of the Contracting Party of the Convention because of its political status in the United Nations. The Taiwanese government introduced a legal standard directly from this international treaty without considering its own domestic legal systems and authorizations. Taiwan voluntarily implemented the principle of the Convention, but did not consider that the fundamental requirement of this principle requires various methodologies and scientific data regarding wetland resources. Generating such scientific data and conducting the necessary investigation requires time, research, and funding and are imperative in making decisions regarding wise use of wetland resources. The lack of fundamental, scientific data on wetland resources leads to failed implementation and enforcement. Proper preparation of the scientific data necessary for the wetlands in island can take over one year. The major concern for the implementation of this principle has been modified and improved by the Conference of the Contracting Parties after 1987. The decision made by the conference has updated the conceptual framework and guidelines of the "wise use" principle. Because Taiwan is not a Contracting Party to the Ramsar Convention, it cannot participate in the real time negotiation and 
update of the wise use principle. Instead, Taiwan must go through the legislative process. Additional time is needed to update and change its legal definitions and negotiation within various levels. If Taiwan could join the negotiation of the Ramsar Convention, the Administrative Branch could more easily adopt a new definition of the wise use principle. The government restricted its definition in 1987 on the Wetland Act, and the Judicial Branch cannot use an updated concept on any related issue. The extension of the implementation date of the Wetland Act to February 2015 is a useful opportunity for the government to establish the scientific data and database for wetlands.

\section{Framework and Structure}

Based on the principles of biological diversity conservation and wise use, the Wetland Act created four conceptual structures to design its eight chapters that will manage wetland resources in Taiwan. The biological diversity conservation principle provides basic concepts to evaluate and delimit the wetland of importance, in addition to providing the guideline for wetland conservation and usage plan evaluation, review, and identification. The usage and management of wetland resources shall follow the "wise use" principle. This principle also applies to development avoidance, impact mitigation, and ecological compensation. The government also established a new wetland fund and label system for conservation management. The penalty articles are provided in the last chapter of the act.

\section{Wise Use Principle}

The first chapter of the Wetland Act is the general principle chapter comprised of seven articles, including the purpose of this new Act. There are multiple authorities in wetland governance. The Ministry of Interior is the assigned authority at the central government level; the municipal governments and city/county governments are the authorities at the local level. Different authorities have different missions. Article 4 provides the definitions of the terms used in this act and clarify the difference between ecological compensation and habitat compensation. Article 5 defines the boundaries of the wise use principle and conservation of both wetland nature resources and ecological function. Article 5 confused the definition in Article 4, subparagraph 4 with the definition of "wise use". According to Article 5, "wise use" requires all levels of government to adopt adequate management and wise use of natural resources and ecological functions for sound, stable ecological system management on a "no net loss" base. Additionally, wise use requires every level of government to promote sustainable development of the entire environment by enhancing wetland conservation and restoration. This article further defines the principle of conservation and wise use in its subparagraphs as

I. "Natural wetlands shall be protected with priority, and the water resource system also maintained.

II. Enhance the conservation of the wetland's plant and animal resources.

III. Wetlands offering ecological network significance and its peripheral environment and landscape shall be adequately and comprehensively planned and maintained.

IV. In coordination with wetland restoration, flood prevention, flood retention, water quality purification, water resource conservation and utilization, landscape and recreation, an overall planning shall be promoted for the wetland system. If necessary, constructed wetlands may be created in proper areas by suitable means [2]." 
Subparagraphs I and II of Article 5 discuss issues on restoration and conservation, but not the usage of wetland resources. Subparagraphs III and IV mention conservation planning, but not use of wetland resources. Comparing Article 5 with the terms used in Article 4, "wise use" is defined as:

"Referring to a timely, fittingly, moderately and adequately sustainable utilization of the biological resources, water resources and land resources that is achieved in a compatible approach within the wetland ecological capacity to maintain the quality and quantity of wetland resources in a stable condition [2]."

This Article mentioned sustainable utilization of wetland resources. In reviewing the terms used in Article 5, one finds a greater focus on conservation and restoration, but not wise use. Having two different definitions of wise use in the same Wetland Act is a source of some confusion. Article 4 is designed to define terms and norms used in this new law, while Article 5 provides general principles on wetland conservation and management. Obviously, Article 5 has more influence on related measures and policies on wetland resource management and usage. Although Article 4 provides a general definition of wise use, it defines the legal norms only, but does not create a guideline or standard function on the related measures and policies. The general definition of norms and terms cannot replace the general principle function. Such a discrepancy may adversely affect the implementation of the "wise use" principle or lead to a wrongful interpretation of the conservation principle that would involve the elements of "wise use" principle.

The Ministry of Interior explained the wise use principle used in this new Act was taken from the Resolution of Ramsar Convention in 1987. Based on the Annex of Recommendation 3.3 of the 3rd Meeting of the Conference of the Parties of Convention on Wetlands in 1987, "wise use" is defined as the following:

"The wise use of wetlands is their sustainable utilization for the benefit of humankind in a way compatible with the maintenance of the natural properties of the ecosystem" [7].

In this international legal document, the elements of the wise use principle are "sustainable utilization" and "natural properties of the ecosystem." [7,8,9] The definition in Article 4 of the Wetland Act did not adopt the terms of "natural properties of the ecosystem," but used the terms "ecological capacities" and "biological resources" in the text. The seventh Meeting of Ramsar COP adopted "ecological character" in 1999. [10] It is obvious that Taiwan's Wetland Act neither adopts the "nature properties of the ecosystem" definition made in the 1987 Recommendation nor the "ecological character" definitions made in the 1997 Ramsar Resolutions. However, the text of Article 4 is more similar to the wording in the 1987 Recommendation document because they both mentioned water, soil, and other natural resources. In Taiwan's Wetland Act, the use of natural resources is different from the usage of ecological resources in the Wetland Act. There is no further definition of the term of ecological capacities in Article 4 or the text of other articles. Whether the term ecological resources is equal to the Ramsar Convention is not clear and may be left to the judicial authority for further explanation. However, the later Ramsar Resolution updated the concept of the wise use after 1987. Since the Taiwan government insisted on the adoption of the "wise use" definition made by the Regina Meeting in 1987, the court may be limited to its use and will not be able to accept the new definition included in the 
ecological characteristic terms after 1990 and 1996. [11] Therefore, the implementation and enforcement on the wise use on the wetlands of this island is worth further observation.

\section{Wetlands of Importance}

Article 8 of the Wetland Act refers to the wetlands identified by this Act as Wetlands of Importance. A Wetland of Importance is classified in three levels: the international level, national level, and regional level. The competent central government authority uses eight standards to evaluate and identify a Wetland of Importance, including biodiversity of the wetland, natural elements, habitat of migratory species, presence of rare and endangered organisms, water and soil, historical culture, folklore heritage, landscape aesthetics, and ecological function. A Wetland of Importance can also be amended or abolished when wetland status is changed by natural disaster or is faced by the need of public interest. In comparing this with the conservation principle described in Article 5, determining how to evaluate the need of public interest and conservation of a Wetland of Importance became a challenge on the government.

A public hearing and participation for any evaluation and abolishment of Wetland of Importance are necessary and required by Article 10. Article 10 also requires public notice for an evaluation that shall be announced and posted to public media thirty days before the evaluation meeting is hosted. The competent central government authority shall consider all suggestions and opinions from the general public. The government shall also prepare proper responses to the public's related opinions and publish them in the public media. These regulations adopted democratic procedures and expanded the opportunity for public participation. These regulations for public participation not only disclose related information on wetland resources, but also increase the awareness for wetland protection.

Thus far, the central government authority has not established procedures for evaluation and abolishment meetings. The lack of established procedures is important as the government begins reorganizing from its 2013 structure. As part of this reorganization, the central government authority over wetland protection may be shifted from the Ministry of Interior to the "Ministry of Natural Resources and Environmental Protection" [12]. It is unclear whether the government can establish the required public hearing procedure before the implementation date.

\section{Utilization Plan on Wetland of Importance}

Article 13 requires the competent central government authority to produce the National Wetland Conservation Guideline every five years to promote wetland conservation strategies and mechanisms. A Utilization Plan on Wetlands of Importance is also required. They shall be proposed and prepared by the competent government authorities in three levels of Wetland of Importance. The Utilization Plan on Wetland Conservation shall not only follow the conservation principle, but shall also state twelve subject matters described in Article 15 of the Wetland Act [13]. In order to confirm the water supply of a Wetland of Importance, the fifth paragraph of Article 15 requires the central government authority to jointly define the standards of water resources within the Wetland of Importance with related government agencies, which included definitions of irrigation, drainage, reservoir, supply, and underground water.

The Wetland of Importance shall be divided into five areas based on ecological function. These areas include core conservation area, ecological restoration area, environmental education area, service area, 
and others. The development and construction in core conservation areas and ecological restoration of international and national Wetland of Importance is strictly prohibited.

The Utilization Plan for the Wetland Conservation Act shall be prepared and formulated within one year after the evaluation announcement is published to the general public and media. The publication and evaluation procedures on the Utilization Plan on Wetland Conservation are similar to the procedure of the Wetland of Importance evaluation. The utilization plans shall be reviewed every five years after their announcement and implementation.

\section{Wise Use on Wetlands of Importance}

Based on the conservation principle, natural wetlands will be protected as a priority. When the government is preparing a national park, regional plan, or urban plan, Article 20 requires the government to consult the central government authority if the border of the plans overlap with a Wetland of Importance. The reviewing or developing of a hydrological plan and soil conservation plan will be subject to consultation by the central government authority to prevent possible influence on a Wetland of Importance. Those who implement the environmental impact assessment shall also consult the central government authority if the development project could potentially impact the Wetland of Importance. When other agencies are reviewing or planning a development project, they shall consult with the central government authority as well.

The Wetland Act recognizes any building or land used for agriculture, fisheries, or salt-making industries located within the border of a Wetland of Importance as a continuing condition. If the use of the land violates any other regulation, the other regulation shall be adopted to address those issues. The Wetland Act identified three industries (agriculture, fisheries, and salt industries) that are permitted to operate within a border of a Wetland of Importance. However, land usage and regional plans in Taiwan are always mixed with various industries. Whether the other industries located within the parameter of a Wetland of Importance could be eliminated depends on the enforcement of all levels of governments after the implementation date. Additional efforts to investigate every activity in the scope of the Wetland of Importance are necessary for establishing a date for decision-making, but these efforts will consume time and financial resources. Furthermore, there are concerns regarding the stakeholders near a Wetland of Importance because Article 20 permits only three industry activities (agriculture, fisheries, or salt-making industries) within the border and determines methods to deal with various stakeholders, and beneficiaries of the interest on the wetlands might be a challenge.

If the utilization of the continuing conditions causes significant impact on the Wetland of Importance, the government authorities shall order the developer, managing entity, or user to improve their utilization measures by a prescribed date. If necessary, the government authorities may provide consultation to improve the utilization measures to a standard of "wise use." The term "wise use" is defined in Article 4. If the utilization is overdue or the improvement failed to fit wise use and caused net loss in a Wetland of Importance, the violators will be penalized and the government will implement impact mitigation, offset compensation, and ecological compensation as described in Article 27.

The owner of private land located on a Wetland of Importance shall not increase facilities or extend the facility's surface area. The owner must obtain a permit from the government authorities for any changes made to the land. 
For any privately owned land located within the border of a Wetland of Importance, the government authorities can adopt proper regulations to expropriate, allocate, or lease the land for a conservation utilization proposal when necessary. Any public land within the border of a Wetland of Importance may be commissioned to private operator with permission from the government authority. Those operators who are earning profits and running travel services shall apply for a permit from the government authority and pay a specific percentage of the profit as rebates. Other prohibited activities are described in Article 25. These prohibited activities include emitting any pollutant, hunting, and drawing water resources.

\section{Development Avoidance, Impact Mitigation, and Ecological Compensation}

Although natural wetlands are a prioritized protected resource, Article 27 allows for the development and utilization on wetlands, except for in those wetlands designated as a Wetland of Importance. The development and utilization on the wetland shall be reviewed with a Wetland Impact Report and approved by government authorities. The reviewing principle mandates following the orders of avoidance, mitigation, offset, and compensation described in the first paragraph of Article 27. The offset and compensation measures and standards will be produced and announced by the government authorities.

This article's text is fundamentally similar to the Resolution XI. 9 adopted by the 11 th Meeting of the Conference of the Parties to the Ramsar Convention [14]. The issue here is the definition of "wise use" in Taiwan's Wetland Act. The act used the term "ecological characteristic" in its text, but explained that the idea was developed from the 1987 definition and used the term of "ecological capacities" in the text. The concept of avoidance, mitigation, offset, and compensation was not developed in 1987. Before the government creates the measures and standards for offset and compensation, it must consider whether it could adopt the standards suggested by the Ramsar Resolution in 2012. This is a concern because Taiwan is not bound by the Convention and its 1987 "wise use" definition. The central government authority shall not only create these standards and measures by making Enforcement Rules for this Act, but will also address the interpretation of the term ecological capacity. The Annex on the 2012 Ramsar Convention was established and based on the core concept of ecological characteristic, but not ecological capacity, which is used by Taiwan's Wetland Act. The basic concept of offset and compensation provides different reviewing standards and measures on wetland protection. The government shall consider this fundamental discrepancy and carefully implement explanations of these different terms. Therefore, joint cooperation and research between the science and social science profession is necessary and essential. If they fail to do so and adopted the suggested guidelines from the international documents, it will lead to many legal concerns and various conflicts on choosing the proper standard. Because the Enforcement Rules of the Wetland Act have not been established, the government still has a limited amount time to work on these critical interpretations on different terms of ecological capacities and ecological characteristics.

\section{Others}

The Wetland Act also established the Wetland Fund for the implementation needs of wetlands conservation measures and policies. The financial sources for the Wetland Fund come from government finances, rebates, interests from the fund management, and other sources. The usage of the fund is limited 
to specific purposes described in Article 34, including promotion of the awareness on wetland conservation and protection, research and monitoring, education, and others.

In order to encourage public participation on wetland conservation and promote wetland environmental education, the central government authority shall establish wetland label and pay specific rebates to the Wetland Fund. The management measures, policies, and audition rules on wetland label system shall be established and announced by the competent central government authority.

\section{Conclusions}

A wetland is a complex system and its management measures rely on dependable scientific data for better conservation. The new Wetland Act passed in a very short time, and now, only has a one-year implementation period. So far, most of the policy surrounding Taiwan's wetlands are lacking scientific detail and biological data for further conservation planning. However, the Taiwanese government has identified over eighty-four Wetlands of Importance on the island [15]. Identifying the wetlands became a concern because the border of those wetlands may overlap with some private land, and related land acquisition or leasing rules or procedures are not yet established. The government may face various challenges from private landowners regarding border allocation. Without further preparation and scientific data to explain and negotiate with neighboring stakeholders, it will be difficult to promote public participation in wetland conservation and protection. The definition of "wise use" is also a great concern in the ongoing rule-making because its definition was self-created, but does not follow the definition given by the Ramsar Convention. However, the government claimed the Ramsar Convention is its major legal resource for future policy-making, citing the term "ecology capacities" used by the Wetland Act. The government will need to further clarify and defined the difference between "ecological characteristic" and "ecological capacity" in order to determine other guidelines related to "wise use" of Taiwan's wetlands. Taiwan's Wetland Conservation Act will be implemented in 2015. We expect the wetland resources in Taiwan to be well protected by strong enforcement and competent implementation of the regulations. The legal community will be conducting further research and paying close attention to the interpretation of the legal standards in this new law as it moves forward.

\section{Acknowledgments}

The author would like to give his special thanks to the Ministry of Science and Technology Republic of China (Taiwan) for the continuing support on this research (MOST 101-2627-B-005-005).

\section{Conflicts of Interest}

The author declares no conflict of interest.

\section{References and Notes}

1. The Wetland Conservation Act. The Legislative Yuan Gazette, 2013.

2. The Wetland Conservation Act. President Office Gazette, 2013.

3. The Wetland Conservation Act. The Executive Yuan Gazette, 2014.

4. Convention on Wetlands of International Importance Especially as Waterfowl Habitat, 1971. 
5. International Union for Conservation of Nature (IUCN). The IUCN Red List of Threatened Species, February 2014. Available online: http://iucnredlist.org (accessed on 22 August 2014).

6. The Basic Environment Act. President Office Gazette, 2002.

7. Wise use of wetland: Annex, Definition of wise use, Recommendation 3.3, Ramsar Convention: Regina, Canada, 27 May-5 June 1987. Available online: http://ramsar.rgis.ch/cda/en/ramsardocuments-recom-information-on-wise-use/main/ramsar/1-31-110^23129_4000_0_ (accessed on 10 December 2014).

8. Annex to the Convention on Wetlands, Recommendation 3.3, Ramsar Convention: Regina, Canada, 27 May-5 June 1987. Available online: http://ramsar.rgis.ch/cda/en/ramsar-documents-recominformation-on-wise-use/main/ramsar/1-31-110^23129_4000_0__(accessed on 10 December 2014).

9. Bowman, M.J. The Ramsar Convention Comes of Age. Netherlands Int. Law Rev. 1995, 42, 1-52.

10. Pritchard, D. Wise Use of Wetlands: Concepts and Approaches for the Wise Use of Wetlands, 4th ed.; Ramsar Handbooks for the Wise Use of Wetlands; Ramsar Convention Secretariat: Gland, Switzerland, 2010; p. 6.

11. Additional Guidance for the Implementation of the Wise Use Concept, Resolution 5.6, Ramsar Convention: Kushiro, Japan, 9-16 June 1993; Guidelines for the Implementation of the Wise Use Concept, Recommendation 4.10, Ramsar Convention: Montreux, Switzerland, 27 June-4 July 1990. Available online: http://ramsar.rgis.ch/cda/en/ramsar-documents-resol-additional-guidance-for/main/ ramsar/1-31-107^20915_4000_0__(accessed on 10 December 2014).

12. Amendment on Executive Yuan Organization Act. President Office Gazette, 2010.

13. The twelve matters described in Article 15 are "I. he border and year period of the plan; II. The guidance of the superior and relevant programs; III. The investigation and analysis of local society and economy. IV. The rudimentary investigation and analysis of water resource system, ecological resources and environment. V. Land and building utilization status. VI. Primarily protected areas with critical scientific search, cultural heritage and ecological and environmental value. VII. Stipulations or measures governing the wetland system functional zoning, and its conservation, restoration, restricted or banned conducts, and maintenance. VIII. Permissible wise use items and management. IX. Water resource protection and utilization management. X. Emergency response and recovery. XI. Financial and implementation. XII. Other pertinent matters."

14. Annex, An Integrated Framework and Guidelines for Avoiding, Mitigating and Compensating for Wetland Losses, Resolution XI.9, Ramsar Convention: Bucharest, Romania, 6-13 July 2012. Available online: http://ramsar.rgis.ch/pdf/cop11/res/cop11-res09-e.pdf (accessed on 10 December 2014).

15. Map of Taiwan's Wetlands, Construction and Planning Agency Ministry of Interior. Available online: http://wetland-tw.tcd.gov.tw/WetLandWeb/web-en/map-wetlands.html (accessed on 26 August 2014).

(C) 2014 by the authors; licensee MDPI, Basel, Switzerland. This article is an open access article distributed under the terms and conditions of the Creative Commons Attribution license (htt://creativecommons.org/licenses/by/4.0/). 